2001

\title{
Lessons from Abroad: Complexity and Convergence
}

Linda S. Mullenix

Follow this and additional works at: https://digitalcommons.law.villanova.edu/vlr

Part of the Civil Procedure Commons, and the Torts Commons

\section{Recommended Citation}

Linda S. Mullenix, Lessons from Abroad: Complexity and Convergence, 46 Vill. L. Rev. 1 (2001).

Available at: https://digitalcommons.law.villanova.edu/vlr/vol46/iss1/1

This Lecture is brought to you for free and open access by Villanova University Charles Widger School of Law Digital Repository. It has been accepted for inclusion in Villanova Law Review by an authorized editor of Villanova University Charles Widger School of Law Digital Repository. 


\title{
VILLANOVA LAW REVIEW
}

\section{Reuschlein Lecture}

\section{LESSONS FROM ABROAD: COMPLEXITY AND CONVERGENCE}

\author{
LindA S. MULLENIX*
}

\section{INTRODUCTION}

$I^{N}$ $\mathrm{N}$ the mid-1970s, Professor Abram Chayes published one of the most famous law review articles ever written, The Role of the Judge in Public Law Litigation, ${ }^{1}$ which described a paradigm-shift with the emergence of public interest law in the $1960 \mathrm{~s}^{2}$ As I have written elsewhere, Professor Chayes' model no longer holds either descriptive or prescriptive power at the end of the twentieth century. ${ }^{3}$ The public interest law paradigm Professor Chayes described fails as a model for the complex litigation that the American judicial system has experienced in the last twenty years.

Without repeating that critique, two observations are in order. First, modern complex litigation, particularly mass tort litigation, is being resolved in ways that resemble private legislation, negotiated and approved

* Bernard J. Ward Centennial Professor of Law, University of Texas School of Law. Harold Gill Reuschlein Distinguished Visiting Chair, Villanova University School of Law, Spring 2000. B.A., The City College of New York, 1971; M. Phil., 1974, Ph.D., 1977, Columbia University; J.D., Georgetown University Law Center, 1980. I am grateful to the Villanova University School of Law and the Harold Gill Reuschlein Distinguished Visiting Chair for the hospitality and support provided to me during spring 2000 . This article was prepared with the research assistance of Michael Ryan Jenness, Villanova University School of Law, Class of 2001. Versions of this paper were delivered at the Association of American Law Schools Annual Meeting, Section on Civil Procedure, "Civil Procedure in the Twenty-First Century" (January 8, 2000), and as the Reuschlein Lecture, Villanova University School of Law (April 7, 2000).

1. Abram Chayes, The Role of the Judge in Public Law Litigation, 89 Harv. L. Rev. 1281 (1976) [hereinafter Chayes, The Role of the Judge].

2. See id. at 1302 (describing public law litigation model that "reverses many of the crucial characteristics and assumptions of the traditional concept of adjudication"); see also Abram Chayes, Foreword: Public Law Litigation and the Burger Court, 96 Harv. L. Rev, 4, 8 (1982) [hereinafter Chayes, Public Law Litigation] (noting Burger Court's lack of hospitality toward public law litigation).

3. See Linda S. Mullenix, Resolving Aggregate Mass Tort Litigation: The New Private Law Dispute Resolution Paradigm, 33 VAL. U. L. Rev. 413, 414 (1999) (stating that Chayes' public law paradigm is no longer accurate). 
by unelected people. ${ }^{4}$ This private legislation-most often class action settlement-affects thousands and, in some instances, hundreds of thousands of citizens. 5 Second, a new descriptive paradigm is needed to capture both the essence and the nuance of the complex litigation that the American judicial system has experienced at the end of the twentieth century.

Scholars who posit models or describe paradigm shifts chiefly are engaged in the enterprise of re-evaluation of facts. ${ }^{6}$ That is, new descriptive models emerge from a fresh appreciation of facts, replacing former orthodoxy. ${ }^{7}$ This is certainly what Professor Chayes did in describing the emergence of the public law model. Professor Chayes viewed the litigation landscape of the 1960s that gave rise to the modern class action rule, structural injunctions and institutional reform litigation. He assimilated these facts and reconstructed prior litigation theory that had been based on a model of bipolar litigation. ${ }^{8}$

While it is difficult enough to describe a model of complex litigation at the end of the twentieth century, it is perhaps even more challenging to forecast the future of complex dispute resolution. History has taught that adjective law-civil procedure-is not static. ${ }^{9}$. In particular, complex litigation has pushed the boundaries of civil rules that were designed for simple litigation. Therefore, the globalization of social and economic transactions in the twenty-first century will affect complex litigation, and the procedures for resolving complex disputes will be informed by legal lessons from abroad.

Regarding complex dispute resolution, the future of complexity is more complexity. Complex systems tend to become more complex. Moreover, procedural rules develop in a dialectic. Thus, systems tend to start with simple rules, but over time rules tend to become longer, more

4. See id. (describing that in new era of aggregate private dispute resolution, private parties and judicial surrogates wield vast power to resolve aggregate claims).

5. See id. at 440 (describing minimal role clients play in litigation although consequences of any settlement may affect up to hundreds of thousands of people).

6. See Thomas S. Kuhn, The Structure of Scientific Revolutions 7 (2d ed. 1970) (stating that new theory reflects upon studies and work already successfully completed).

7. See id. ("A new theory, however special its range of application, is seldom or never just an increment to what is already known. Its assimilation requires the reconstruction of prior theory and the reevaluation of prior fact, an intrinsically revolutionary process ....").

8. See Chayes, The Role of the Judge, supra note 1 , at 1282 (noting that traditional civil litigation is bipolar because "[l]itigation is organized as a contest between two individuals or at least two unitary interests, diametrically opposed, to be decided on a winner-takes-all basis").

9. See Mullenix, supra note 3, at 419 (describing 1966 revision of Federal Rules of Civil Procedure). 
nuanced, textured and complex. ${ }^{10}$ In the past twenty years, almost every rule revision has yielded a lengthier and more convoluted rule, as the drafters have attempted to provide solutions for every problem and contingency. ${ }^{11}$

Part of this dialectic is that the impulse towards complexity inevitably leads to reform and simplification. At some point, when the rules have become so complex, intricate and obtuse-creating traps for the unwary $^{12}$-reformers avow to eliminate the rules and start again, with simple rules. This dialectic impelled the great procedural reforms of the nineteenth century ${ }^{13}$ that famously resulted in the creation of "one civil action" 14 and, in one simple declaration, swept away centuries of procedural cobwebs with the abolition of the forms of action. ${ }^{15}$

At the end of the twentieth century, it is difficult to perceive where the civil rules are in the context of this dialectic. Have the civil rules become sufficiently complex that, in the twenty-first century, the rulemakers will embark on another age of procedural reform? Will the rulemakers again feel the need to declare, anew, that there will be one form of action, and it will be a simple action? Or, in this dialectic, will the rulemakers abandon the grand experiment with trans-substantive rules and revert back to substance-based procedure? ${ }^{16}$

History also has demonstrated that the judicial system lacks the forecasting powers to anticipate new problems. Attorneys, judges and rulemakers simply cannot know what kinds of problems, disputes or grievances will emerge to challenge the role of the judiciary. Jurists, then, typi-

10. For example, the current version of the Federal Rules of Civil Procedure is considerably longer than the original 1938 Rules.

11. Federal Rules of Civil Procedure 4 and 16, both amended in 1993, are good examples of textual sprawl. See Michael E. Tigar, Pretrial Case Management Under the Amended Rules: Too Many Words for a Good Idea, 14 Rev. LrTic. 137, 157 (1994) (describing prolix amendment of Federal Rule of Givil Procedure 16 in 1993). See generally Symposium, Turbulence in the Federal Rules of Civil Procedure: The 1993 Amendments and Beyond, 14 Rev. LiTIG. 1 (1994) (dealing with 1993 amendments to Federal Rules of Civil Procedure).

12. See Fleming James, Jr., et al., Civil Procedure $\$ 1.6$ (4th ed. 1992) ("Too often, mistakes of form led to loss of a suit by the party entitled to win on the merits.").

13. See id. $\S 1.7$ (noting procedural reforms in United States and England).

14. Id. $\S 1.8$; see also FED. R. Crv. P. 2 ("There shall be one form of action to be known as 'civil action.'").

15. See James, supra note $12, \S 1.8$ (describing enacting of Federal Rules of Civil Procedure in 1938); see also FED. R. Crv. P. 7(a) ("No other pleading shall be allowed ...."); Fed. R. CIV. P. 7(c) ("Demurrers, pleas, and exceptions for insufficiency of a pleading shall not be used.").

16. See, e.g., Mark C. Weber, The Federal Civil Rules Amendments of 1993 and Complex Litigation: A Comment on Transsubstantivity and Special Rules for Large and Small Federal Cases, 14 Rev. Litig. 113, 120 (1994) (discussing underlying philosophy of transsubstantivity of Federal Rules of Civil Procedure and erosion of this philosophy in certain types of cases). 
cally engage in rule reform after-the-fact, to deal with problems that the rulemakers never anticipated.

In our generation, for example, the most famous illustration of the judicial system's failure to anticipate new problems is the rule drafters' failure in the early 1960s to anticipate modern mass tort litigation. Thus, the Advisory Committee on Civil Rules revised the federal class action rule without knowing what was coming. If the Advisory Committee could not forecast mass torts, what problems will emerge in the next millennium that are not currently foreseeable? There are other examples, of course; but whom at mid-century could have anticipated agent orange, the Dalkon Shield, breast implants, fen-phen or tobacco litigation?

Moreover, in reflecting on the future of complex litigation, it is impossible to ignore the impact of technology and globalization. Technology effectively has enabled international transactions to transcend national borders, and will affect the way in which lawyers conduct their professional activities. Globalization means that business, social and legal transactions will also transcend national borders.

In the twenty-first century, the impact of technology and globalization will result in legal problems of global reach, and lawyers will be practicing on a world stage. Therefore, the American lawyer will need to understand comparative law and how American legal concepts constitute a kind of "outlier" among legal systems. This is especially true regarding the ways in which other legal systems resolve complex legal disputes.

The globalization of legal practice will have other consequences. As complex legal problems transcend national borders, American procedural law may well converge with the adjective law of civil law systems. The pronounced differences between Anglo-American procedure and civil law countries may fade or merge as each system learns from the experiences of the other. The interaction of American lawyers and scholars with civil law colleagues may well spur a convergence of procedural law.

\section{Givil Law Systems: Describing the Differences}

The process of teaching comparative procedure in American law schools is basically an exercise in teaching the differences between American procedure and civil law systems. ${ }^{17}$ Thus, the American comparative

17. See generally Henry J. Abraham, The Judicial Process: An Introductory Analysis of the Courts of the United States, England, and France (7th ed. 1998) (comparing judicial processes of United States, England and France); JAMES G. Apple \& Robert P. Deyling, A Primer on the Cinil Law System (1995) (discussing history and modern civil law); Ruth Bader GinsBurg \& ANDERs Bruzelius, Crill Procedure in Sweden (1965) (describing Sweden's laws of civil procedure to allow comparison between United States procedure and Swedish procedure); Noel, Some Observations on the English, French, German, and American LeGAL SYSTEMS (1997) (observing several different legal systems); MARTIN SHAPIRO, Courts, A Comparative and Political Analysis (1981) (discussing common law, civil law, imperial Chinese, Islamic and communist legal traditions); Ronald J. Allen et al., The German Advantage in Civil Procedure: A Plea for More Details and Fewer 
procedure professor teaches a litany of comparative difference. This standard list canvasses several major areas of difference:

- THE Right to TRIAL BY JURY. In the United States, the right to trial by jury in civil actions is guaranteed by the Seventh Amendment. ${ }^{18}$ In most civil law countries, there is no right to a trial by jury. ${ }^{19}$

- Crvil Discovery. In the United States, the Federal Rules of Civil Procedure contain extensive provisions for discovery of factual information and expert testimony prior to trial. ${ }^{20}$ Since 1938 , the provision for liberal discovery in the Federal Rules has been considered a necessary adjunct to the regime of notice pleading. ${ }^{21}$ In contrast, most civil law countries do not provide for American-style liberal discovery, ${ }^{22}$ or severely

Generalities in Comparative Scholarship, 82 Nw. U. L. Rev. 705 (1988) (describing German and United States "respective approaches to civil procedure, experts, and the qualifications and incentives of judges"); Ronald J. Allen, Idealization and Caricature in Comparative Scholarship, 82 Nw. U. L. REv. 785 (1988) (criticizing comparative law scholarship and pointing out that better scholarship of German and comparative law needs to be produced); Richard S. Frase, Comparative Criminal Justice As a Guide to American Law Reform: How Do the French Do It, How Can We Find Out, and Why Should We Care?, 78 CAL. L. Rev. 542 (1990) (surveying prospects for future reform-oriented research on comparative criminal procedure); John $\mathrm{H}$. Langbein, The German Advantage in Civil Procedure, 52 U. CHI. L. Rev. 823 (1985) (comparing German and American civil procedure); John H. Langbein, Trashing the German Advantage, 82 Nw. U. L. REv. 763 (1988) (noting advantages within German civil procedure); John Henry Merryman, How Others Do It: The French and German Judiciaries, 61 S. CAL. L. REv. 1865 (1988) (comparing United States with French and German judiciaries).

18. See U.S. Const. amend. VII ("In suits at common law ... the right of trial by jury shall be preserved ....."). See generally JAMES, supra note 12, at $\$ \S 8.1-.3$ (describing constitutional right to jury trial).

19. See Patricia Howlett, Compensation for Drug Induced Fetal Deformities in Common and Civil Law Systems, 2 Touro J. Transnat'L L. 243, 260 (1991) (describing lack of jury trial right in civil law countries and impact of lack of jury trial on resolution of Thalidomide cases in Germany).

20. See FED. R. Crv. P. 26-37 (designating Federal Rules for discovery and depositions).

21. See generally JAMEs, supra note 12, $\$ \$ 5.1-.2$ (discussing historical background and emergence of broader role for discovery).

22. See Christopher Joseph Borgen, International Legal Developments in Review: 1997 (Discovery), 32 INT'L LAw. 237, 240 (1998) (describing relationship of Federal Rules of Civil Procedure to foreign discovery rules); Elie Kleiman, Latest Developments in Cross-Border Litigation: Discovery and Injunctive Relief-A French Perspective, 12 INT'L LAW PRACTICUM 5, 5 (1999) ("In civil law countries, discovery as it is known in the United States does not exist as such, although in France certain procedural remedies, known as investigative measures (mesures d'instructions), are available for fact-finding purposes."); Daniel Soulez Lariviere, Overview of the Problems of French Civil Procedure, 45 AM. J. Comp. L. 737, 738 (1997) (noting absence of notion of civil discovery in France, common to civil law jurisdictions); Russell J. Weintraub, Critique of the Hazard-Taruffo Transnational Rules of Civil Procedure, 33 TEx. INT'L L.J. 413,420 (1998) (" $[\mathrm{T}]$ here is widespread disapproval of pretrial discovery of documents as that discovery is conducted in the United States . . . ."). See generally Societe Nationale Industrielle Aerospatiale v. United States Dist. Ct. of lowa, 482 U.S. 522, 539 (1987) (holding that idea of international comity does not require first use of Hague Convention principles before initiating discovery under Federal 
restrict discovery by "blocking statutes." ${ }^{23}$ At any rate, no other country in the world has any system of discovery approaching that provided for in the Federal Rules of Civil Procedure.

- Financing Litigation and Attorneys' FeEs. In the United States, the "American Rule" provides that each side of the litigation pays its own litigation costs, expenses and attorney fees (with some statutory fee-shifting exceptions). ${ }^{24}$ Contingency fee contracts are permissible (and usual) in certain types of litigation-most prominently personal injury and other tort litigation. ${ }^{25}$ Also, plaintiffs' attorneys are permitted to front the costs of contingent litigation. ${ }^{26}$ In contrast, civil law countries follow the "loser pays" rule, prohibit contingency fee contracts, and do not permit attorneys to front the costs of litigation. ${ }^{27}$

- THE Role of the ENTRepreneurial LaWYer. The American legal system has fostered and encouraged the so-called "entrepreneurial" lawyer who, with a vested interest in the litigation, pursues and vindicates client

Rules); Laura W. Smalley, How to Conduct Intermational Discovery, 71 AM. JURIs. TRIALS 1, \$ 1 (1999) (discussing Hague Convention on Taking of Evidence in Criminal and Civil Matters).

23. See, e.g., Weintraub, supra note 22, at 420 (noting that of twenty-eight signatories of Hague Convention, nine have invoked right to refuse any pretrial discovery of documents and twelve have made significant reservations that permit discovery only of limited documents).

24. See JAMEs, supra note 12, $\$ \S 1.21-.22$ (describing "American Rule" and exceptions); Richard B. Cappalli \& Claudio Consolo, Class Actions for Continental Europe? A Preliminary Inquiny, 6 Temp. INT'L \& Comp. L.J. 217, 228-30 (1992) (noting how class action process operates and how, initially, plaintiff's attorney(s) bear economic burden of litigation costs); William B. Fisch, European Analogues to the Class Action: Group Action in France and Germany, 27 AM. J. CoMP. L. 51, 53-56 (1979) (comparing handling of major litigation costs in United States, France and Germany); John G. Fleming, Mass Torts, 42 Aм. J. Comp. L. 507, 519 (1994) (stating that injured Americans have to seek damages for financial losses and physical injury as well as to compensate their own lawyers, who are remunerated by contingency fees); Hein Kötz, Public Interest Litigation: A Comparative Survey, in Access to Justice and the Welfare State 85, 90-93 (Mauro Cappelletti ed., 1981) (describing "American Rule" on attorney fees and citing sources).

25. See Fleming, supra note 24, at 519 (describing American system of contingency fees); Kötz, supra note 24, at 93-94 (describing German loser pays rule).

26. See Cappalli \& Consolo, supra note 24, at 228-29 (noting attorney takes case for contingency fee and even finances litigation costs).

27. See id. at 261 (describing prohibitions against such practices in Italian Code of Civil Procedure); $c f$. Fisch, supra note 24, at 56 (describing legal aid in civil cases in France and Germany); Geraint G. Howells, Mass Tort Litigation in the English Legal System: Have the Lessons from Opren Been Learned?, in 15 UNITED KINGDOM Comparative Law Series 519, 610-13 (John W. Bridge et al. eds., 1994) (describing Legal Aid Act of 1988 and Legal Aid Board Multi-Party Action Arrangements of 1992 for contracting out legal representation to law firms and noting equities involved in financing group litigation). 
claims. ${ }^{28}$ This system of entrepreneurial lawyering is incompatible with civil law systems. ${ }^{29}$

- Punitive Damages. In the United States, most states (and federal courts) recognize punitive damage claims. ${ }^{30}$ Most civil law countries, however, do not recognize punitive damage claims. ${ }^{31}$ In those countries, punitive damages simply are not available.

- AgGregate Tort Damages. In the United States, courts have recognized the ability to award aggregate tort damages. ${ }^{32}$ Civil law countries do not recognize the ability to award aggregate personal injury tort damages. ${ }^{33}$

- Class Actions. The Federal Rules of Civil Procedure provide for class action litigation, ${ }^{34}$ as do most states. ${ }^{35}$ Almost all civil law countries, as well as England (a common law country), do not have a class action procedure. ${ }^{36}$

28. See Cappalli \& Consolo, supra note 24, at 288 (describing concept of American entrepreneurial lawyer).

29. See id. at 290 (describing differences between American concept of entrepreneurial lawyer and civil law systems).

30. See Courtland H. Peterson \& Joachim Zekoll, Mass Torts, 42 Aм. J. Comp. L. 79, 99-101 (1994) (stating that use of punitive damages is well established in civil tort cases).

31. See id. at 99 (noting punitive damage awards are often regarded with suspicion in other legal systems).

32. See, e.g., Hilao v. Estate of Marcos, 103 F.3d 767, 782-87 (9th Cir. 1996) (upholding award of aggregate damages based on statistical sampling).

33. See Howells, supra note 27 , at 607 (commenting on inapplicability of aggregate or representative tort damages in Great Britain; Michele Taruffo, Group Actions in Civil Procedure, in Italian National. Reports to the. XIIIth InternaTIONAL Congress of Comparative LaW, Montreal 173, 173-75 (1990) (noting that features of Italian system of civil procedure result in inability to award aggregate personal injury tort damages; claims are treated separate and individually); see also Kötz, supra note 24, at 107 ("In recent years, various bold proposals have been made in Germany trying to adapt the American class action to the German environment and, in some way, to provide consumers' associations with standing to sue for aggregated damages. These proposals have met with strong resistance by industry.").

34. See FED. R. CIV. P. $\$ \S 23-23.2$ (stating class action rules).

35. See generally Linda S. Mullenix, State Class Action Practice and ProceDURE (CCH 2000) (noting that " $[\mathrm{m}]$ ost states have promulgated a class action rule based on Federal Rule of Civil Procedure (Fed. R. Civ. P.) 23, the federal class action rule" and observing that some other states "have adopted the Uniform Law Commissioner's Model Class Actions [Act] [Rule]").

36. See Mauro Cappelletti \& Bryant Garth, The Protection of Diffuse, Fragmented and Collective Interests in Crvil Litigation 117, 144 (1983) (noting class actions are not found outside of common law countries); Howells, supra note 27, at 604 (stating that English system lacks specific class action procedure similar to Federal Rule of Civil Procedure 23); Taruffo, supra note 33, at 173 ("The first negative feature in the Italian system of civil procedure is that it has no general devices aimed at fostering group actions."); Cappalli \& Consolo, supra note 24, at 218-20 ("The class action is a unique American legal institution."); Fleming, supra note 24, at 520-23 (commenting on other jurisdictions' lack of interest in class action litigation); Harald Koch, Class and Public Interest Actions in German Law, 
- THE ROLE OF THE JUDGE. In the United States, the central animating value in the legal system is the concept of adversariness. ${ }^{37}$ Within this system, the role of the judge is conceived as that of the neutral arbiter, tasked with the narrow role of determining issues of law. ${ }^{38}$ The judge is not a fact-finder. ${ }^{39}$ There is no professionalized judiciary and no specialized training for judges (prior to appointment or election to the bench) ${ }^{40}$ In civil law countries, the model of the inquisitorial judge is almost the opposite. The civil law judge is the fact-finder, an active participant in legal proceedings and the ruler on issues of law. ${ }^{41}$ In civil law countries, the judiciary is highly professionalized and judicial aspirants elect a course of study in preparation to serve as a judge after the award of academic degrees. ${ }^{42}$

- Evidentiary Standards and Allocation of BuRdens of PRoOf. In the United States, trial procedure and the admissibility of evidence are governed by the Federal Rules of Evidence, which circumscribe the ability to adduce proofs. ${ }^{43}$ In addition, the plaintiff carries the burden of production and proof. ${ }^{44}$ Most civil law countries, however, do not recognize or apply evidentiary rules as stringently as the United States, and civil law courts often allow various forms of evidence and testimony. ${ }^{45}$ In addition, in various civil claims, many civil law countries shift the allocation of burdens of production and proof to the defendant. ${ }^{46}$

5 Crv. Just. Q. 66, 77 (1986) (noting that there is no general provision in German law concerning representation of groups or class interests).

37. See generally JamEs, supra note $12, \S 1.2$ (describing adversary system as leading characteristic of Anglo-American procedural system).

38. See id. $\S \S 7.19-.20$ (describing judge's role in examining sufficiency, admission and exclusion of evidence, all of which are issues of law); Peterson \& Zekoll, supra note 30, at 102 (noting that role of judge in American common law system is that of passive arbiter of conflicting individual interests).

39. See JAMES, supra note $12, \S 7.2$ (pointing out that litigants have right to jury trial unless neither party invokes right, in which case trial judge determines facts).

40. See Fleming, supra note 24, at 528 (describing role of common law judiciary as "familiar model of passive, not inquisitorial judges"). But $c f$. JAMEs, supra note $12, \S 1.2$ (describing federal judge's responsibilities as non-passive role).

41. See Howlett, supra note 19, at 265 ("In the civil system, the judge questions the witness, the accused and the victim to help determine the truth.").

42. See id. at 260-61 (describing role of professionalized German judiciary in resolving thalidomide litigation).

43. See generally Fed. R. Evid. (placing limits on ability to adduce proofs); JAMES, supra note $12, \S 7.19$ (addressing sufficiency of evidence); $i d$. at $\$ 7.20$ (addressing admission and exclusion of evidence).

44. See JAMEs, supra note $12, \S 7.5$ (addressing standards of proof); id. $\S 7.15$ (addressing burden of producing evidence); id. $\$ 7.16$ (addressing allocation of burdens of proof).

45. See Howlett, supra note 19, at 259-60, 266. (describing differences in use of evidence in German Thalidomide cases and consequent impact on legal proceedings).

46. See, e.g., Codico de Protecaodo Consumidor Brasileira [Brazilian Consumer Protection Code], Law. No. 8078, Sept. 11, 1990, art. 81 (Braz.) (creating national consumer class actions). 
- STANDING. In the United States, standing to sue is a constitutional requirement and standing concepts have been defined by a substantial body of decisional law. ${ }^{47}$ Although the subject of extensive debate, ${ }^{48}$ authorities suggest that Congress is constitutionally limited in its ability to confer standing to sue in American civil litigation. ${ }^{49}$ In contrast, many civil law systems statutorily confer standing to sue on individuals, groups and associations. ${ }^{50}$

- RES Judicata. In the United States, issue and claim preclusion is governed by an elaborate body of decisional law that operates to prevent relitigation of claims and issues that could have, or should have, been asserted in a prior proceeding against parties and their privies. ${ }^{51}$ In contrast, most civil law countries do not recognize the doctrine of res judicata, or the "binding effect" of prior legal decisions. 52

- Legal Education. In the United States, legal education is a separate post-graduate course of study and separate academic degree. In civil law countries, legal education is part of an integrated undergraduate course of study, with specialized training for a professionalized judiciary and other legal functions. ${ }^{53}$

47. See Lujan v. Defenders of Wildlife, 504 U.S. 555, 560-62 (1992) (holding that environmental groups did not assert sufficiently imminent injury to have standing to challenge Secretary of Interior's regulations and stating formula on standing to sue); Lujan v. Nat'l Wildlife Fed'n, 497 U.S. 871, 890 (1990) (holding that affidavits were insufficient to establish respondent's standing under section 702 of Administrative Procedure Act). See generally Douglas L. Parker, Standing to Litigate "Abstract Social Interests" in the United States and Italy: Reexamining "Injury in Fact," 33 Colum. J. Transnat'L L. 259, 265-72 (1995) (discussing law of standing in United States).

48. See Parker, supra note 47, at 272 (noting that scope of Congress' authority to modify standing to sue is unresolved).

49. See id. at 299 n.138 (reviewing scholarship and case law on issue of Congress' ability to confer standing to sue in civil litigation).

50. See Cappalli \& Consolo, supra note 24, at 269-70 (discussing civil law concepts of standing); CAPPELletTI \& GARTH, supra note 36, at 137-39 (same); Koch, supra note 36, at 77 (discussing standing for associational groups in German law); Kötz, supra note 24, at 104-06 (discussing associational standing in France); Parker, supra note 47 , at 262, 272-98 (discussing standing to sue in Italian system); Taruffo, supra note 33 , at $176-78,188-89$ (same).

51. See generally JAMES, supra note $12, \S \S 11.1-.32$ (discussing judgments, res judicata and preclusion doctrines); Fleming, supra note 24, at 525-26 (discussing doctrine of collateral estoppel); Peterson \& Zekoll, supra note 30, at 102, 120-24 (same).

52. See Cappalli \& Consolo, supra note 24, at 224 (noting Italian legal system does not recognize doctrine of stare decisis); Parker, supra note 47, at 308, 313-15 (discussing impact of Italian legal system lacking doctrine of stare decisis or notion of precedent).

53. See Cappalli \& Consolo, supra note 24, at 263-64 (noting how study of law differs in continental Europe from American study of law). Cappalli and Consolo state:

The study of law in continental Europe is quite unlike our pragmatic,

"problem solving" focus; it is dominated by dogmatics, i.e., a focus on

legal abstractions and the inter-relationship of juridical concepts. In the 
- Sources of Law and Legal Authortty. In the United States, the sources of law and legal authority consist of constitutions, statutes, rules, court decisions, treatises, law review articles and the opinions of legal scholars. ${ }^{54}$ In addition, American courts adhere to the doctrines of stare decisis, ${ }^{55}$ binding precedent and res judicata. ${ }^{56}$ In civil law countries, the opinions of legal scholars provide the most authoritative source for determining the law. ${ }^{57}$ Civil law countries generally do not recognize the doctrines of stare decisis, ${ }^{58}$ binding precedent and res judicata. ${ }^{59}$

- Annexation of Civil Claims to Criminal Proceedings. In the United States, criminal, civil and administrative law proceedings are separate. Each proceeding entails a different burden of production and proof. ${ }^{60}$ In many civil law countries, it is possible to "annex" a civil claim to a criminal proceeding and to seek civil remedies in the context of a criminal proceeding. ${ }^{61}$ The combined criminal-civil proceedings enable a civil claimant to use the resources of the prosecutor's office to pursue civil relief. ${ }^{62}$

- Legal Culture. In the United States, at least according to critics, a culture of grievance and "litigiousness" encourages citizens to resolve any

classroom, the European professor plunges into the comprehensive codes and meticulously extracts every possible meaning, nuance, and cross-reference out of every word and phrase. He likewise endlessly massages concepts when he creates dottrina through his scholarship. This approach moves directly with the Continental lawyer into offices and courtrooms and legislatures, for as Professor Merryman accurately says,

"In civil law jurisdictions, the way legal scholars look at the law is the way Id. everyone looks at it."

54. See generally Christina L. Kunz et al., The Process of Legal Research 5 (4th ed. 1996) (describing legal sources).

55. See Evan H. Caminker, Precedent and Prediction: The Forward-Looking Aspects of Inferior Court Decisionmaking, 73 TEx. L. REv. 1, 10 (1994) (noting importance of prior judicial precedent in judicial decisions).

56. See generally Federated Dep't Stores, Inc. v. Moitie, 452 U.S. 394 (1981) (applying principles of res judicata).

57. See Cappalli \& Consolo, supra note 24, at 264 (noting that "the way legal scholars look at the law is the way everyone looks at it").

58. See, e.g., id. at 224 (stating that Italian legal system does not recognize doctrine of stare decisis); Parker, supra note 47, at 308, 313-15 (same).

59. See Michael J. Waggoner, Fifty Years of Bernhard v. Bank of Am. Is Enough: Collateral Estoppel Should Require Mutuality But Res Judicata Should Not, 12 REv. LiTIG. 391, 39495 n.9 (1993) (noting that "most civil law countries do not have a rule against splitting a claim").

60. See JAMEs, supra note $12, \S 7.14$ (discussing different measures of persuasion in civil and criminal proceedings).

61. See Fisch, supra note 24, at 53-54 (1979) (noting overlap of private and penal law claims in Europe); Howlett, supra note 19, at 252, 262-63, 267 (stating that German legal system permits civil claims to be joined with criminal complaints and tried at one time); Kötz, supra note 24 , at 104-05 (describing ability to annex civil claims to criminal proceedings in France); Taruffo, supra note 33, at 184-86 (describing ability to annex civil claims to criminal proceedings in Italy).

62. See Howlett, supra note 19, at 262-63 (noting role of prosecutor's office). 
and every complaint through litigation. ${ }^{63}$ In civil law countries, by contrast, no such culture of litigiousness exists, and is indeed alien to societal norms. ${ }^{64}$

This list, of course, is not complete. It does not include, for example, generalizations about the vast differences in social and political systems that also have an effect on legal culture. ${ }^{65}$ It does not describe differences in legal structures or institutions. But this survey does provide a sense of how the legal academy thinks about and teaches comparative civil procedure, an exercise in difference that is profoundly pervasive and entrenched. ${ }^{66}$

It is worth noting that American students and the American practicing bar typically recoil from this civil law jurisprudence. ${ }^{67}$ For example, the American plaintiffs' bar is not receptive to a legal system that, in tort

63. See Fleming, supra note 24 , at 519-20 (suggesting greater reliance on judicial process in America).

64. See id. at 520 (noting lack of cultural litigiousness of Swiss and Germans).

65. See id. at 519. Fleming stated:

Disproportionately greater reliance on the judicial process is a well known feature of the American social culture. Many factors contribute to this phenomenon. One of these is the absence of any comprehensive social security or national health system to take care of the basic needs of accident victims. The latter are therefore forced to seek redress through the legal process, whereas the overwhelming majority in other industrialized countries are content with their social security.

Id.; see also Harald Koch, Mass Torts in German Law, in German National RePorts in Civil. Law Matters for the XIVTh Congress of Comparative Law in Athens 67, 83 (Erik Jayme ed., 1994) (commenting on social security system's subrogation rights against tortfeasor).

66. See, e.g., Howard M. Erichson, Mass Tort Litigation and Inquisitorial Justice, 87 GEo. L.J. 1983, 1985 (1999) (discussing state of mass tort litigation in United States). Professor Erichson concludes:

Many U.S. legal commentators have urged broad adoption of aspects of the inquisitorial system. Perhaps these commentators are heartened by the shift taking place in modern mass tort litigation. Perhaps courtappointed experts, settlement class actions with intense judicial oversight, and other inquisitorial approaches are exactly what mass torts need. Perhaps these developments are something of a culmination of the twentyyear trend of managerial judging in the United States.

More likely, however, they are destined for failure, or at least incompleteness, because U.S. judges are ill-equipped for effective inquisitorial judging. Even as we urge judges to use the inquisitorial tools that can help achieve just and efficient resolutions to mass torts, we should note realistically the barriers that stand in the way. As a matter of judicial culture, training and structure, the U.S. judiciary may be poorly positioned to take on substantial inquisitorial responsibilities.

$I d$. at 2010-11. Professor Erichson then supports his conclusion with a litany of the comparative differences between American jurisprudence and civil law systems that serve as barriers to resolving mass torts, as would our civil law colleagues. See $i d$. at 2011-15 (suggesting that adversary system in United States is barrier to inquisitorial justice).

67. This is so notwithstanding the best efforts of American law professors to encourage (if not command) their American students not to make normative comparative assessments of the American and civil law systems. 
actions, does not permit contingency fees, American-style discovery, jury trials or the possible recovery of punitive damages. 68

\section{Complex Litigation ANd Convergence}

Comparative civil procedure then, as a matter of practice and theory, remains a problem in difference. In the next millennium, however, as a consequence of the globalization of complex legal disputes, the differences in American and civil law procedure may well converge in interesting ways. It may turn out that the litany of comparative differences that comparative scholars enumerate does not consist of as great a chasm as they suggest.

Moreover, the convergence of American procedural law with civil adjective law has already begun in many aspects of complex civil litigation. For example, this convergence is nascent, if not already evident, in at least five areas: (1) the role of the judiciary; (2) the right to trial by jury; (3) punitive damages; (4) discovery; and (5) financing aggregate litigation. ${ }^{69}$

In addition, some American jurists have already taken note of and approved the ability, in civil law systems, to annex civil claims to criminal proceedings. ${ }^{70}$ Finally, in another convergence of American and civil law

68. See generally Fisch, supra note 24 (discussing differences in mass tort litigation between United States, France and Germany).

69. See generally Manual for Complex Litigation (3d ed. 1995) (detailing modem management of complex litigation in American system).

70. See, e.g., United States v. Ferranti, 928 F. Supp. 206, 217-18 (E.D.N.Y. 1996) (commenting on France's allowance of annexation of civil claims to criminal proceedings), aff $d$ sub nom. United States v. Tocco, 135 F.3d 116 (2d Cir. 1998). In Ferranti, Senior Judge Jack Weinstein discusses at length the comparative ability in the French criminal-civil system to annex civil claims to criminal proceedings:

The analogous but more developed procedure used by the respected French criminal-civil system demonstrates that restitution as an added feature of criminal law is not inconsistent with due process. The private restitutionary portion of the penalty reflects an important change in the direction of our criminal law to amalgamate tort-like functions with criminal prosecutions .... Private attorney general prosecutions through class actions, whistle blower suits, qui tam actions, fines and compensations by administrative agencies and other quasi-private and quasi-public procedures are developing. They have begun to blur our sharp civil-criminaladministrative law distinctions.

Id.; cf. Georgine v. Amchem Prods., Inc., 83 F.3d 610, 632-33 (3d Cir. 1996) (noting problems with class action suits), aff'd sub nom. Amchem Prods., Inc. v. Windsor, 521 U.S. 591 (1997). Judge Weinstein also noted:

Unlike the still fairly clear line between civil and criminal remedies in Anglo-American law, the French system has long utilized criminal prosecutions to provide for victim compensation. In France, as in most Romanistic legal systems, the victim plays an important part in the criminal proceeding. The principle of discretionary criminal prosecution applies in France with respect to the public prosecutor's office. The victim can, by means of the action civile raise an official complaint even if that is contrary to the wishes of the public prosecutor. The action civile does two things: it initiates a claim for compensation, and it begins a public crimi- 
systems, the United States Congress is now legislatively attempting to solve mass tort litigation that has proven unresolvable in the American courts. ${ }^{71}$ Solving mass tort and environmental disasters through legislative action is a primary means for resolving these disputes in many civil law countries, ${ }^{72}$ a lesson that the United States has been slow to absorb.

\section{A. Convergence: The Role of the Judiciary}

Perhaps the best example of the convergence in the resolution of complex litigation concerns the role of the judiciary. In the standard academic repertoire addressing the American judicial function, the scholarly literature is replete with analysis concerning the differences between the American judge and the civil law "inquisitorial" judge. ${ }^{73}$ But, particularly in the realm of complex litigation, the American managerial judge has undertaken roles that are indeed converging with the civil law inquisitorial judge. ${ }^{74}$ In many respects, then, it is difficult to differentiate between the American judge and his or her civil law counterpart as they deal with complex cases.

nal action .... The United States is in a state of transition on restitution. How far it will move toward an integrated criminal-civil-administrative system in areas such as mass torts or environmental delicts, what effect recovery for restitution will have on the tort law system's collateral benefits rule, how much cooperation there will be between the public prosecutor, administrative agencies and private persons, and many other issues are just beginning to be addressed.

Ferranti, 928 F. Supp. at 218-19 (citations omitted).

71. See, e.g., Fairness in Asbestos Compensation Act of 1998, S. 2546, 105th Cong. (1998) (establishing fair, inexpensive resolution of personal injury claims stemming from asbestos); Class Action Fairness Act of 1998, S. 2083, 105th Cong. (1998) (providing federal class action reform); Class Action Jurisdiction Act of 1998, H.R. 3789, 105th Cong. (1998) (enlarging federal jurisdiction over class actions); Multiparty, Multiforum Jurisdiction Act of 1997, H.R. 1857, 105th Cong. (1997) (providing jurisdiction for some multiparty, multiforum class actions).

72. See, e.g., Howlett, supra note 19, at 257 (describing Japanese legislation to aid victims of Thalidomide disaster).

73. See generally Gerhard Walter \& Samuel P. Baumgartner, Utility and Feasibility of Transnational Rules of Civil Procedure: Some German and Swiss Reactions to the Hazard-Taruffo Project, 33 Tex. INT'L L.J. 463, 467 (1998) (discussing transnational rules and how civil law countries do not grasp United States' adversarial judicial process).

My distinguished colleague Professor Walter, University of Bern Institute for Swiss and International Civil Procedure, has rightly objected to the American usage of the term "inquisitorial" judge to describe the role and function of judicial officers in civil law systems. Professor Gerhard suggests that this American appellation summons pejorative connotations of the Spanish Inquisition, with civil law judges extracting information through use of the rack and screw. See id. at 471 (stating that many commentators do not think common-law and civil systems could be merged).

74. See JaMEs, supra note $12, \$ 1.2$ ("The principle of party-prosecution has been modified in modern judicial administration by the proposition that the court has an affirmative responsibility to move a case along to settlement or trial."). 
Although our judges still are not fact-finders, it is difficult not to take note of the increasing managerial involvement of judges in the resolution of complex cases, often verging on functions such as fact-finding. The Manual for Complex Litigation" ("Manual"), now in its third edition, authorizes and encourages increased judicial involvement in resolving complex litigation. ${ }^{76}$ Although the Manual is not binding authority, ${ }^{77}$ it has become the primary judicial reference text for complex litigation in federal and state courts. ${ }^{78}$

The animating value of the Manual is judicial activism, and the Man$u a l$ is filled with rhetorical passages intended to induce active judicial case management. Thus, in describing the general purposes of the Manual, the text states:

Much complex litigation, therefore, will take the judge and counsel into sparsely charted terrain with little guidance on how to respond to pressing needs for management. Practices and principles that served in the past may not be adequate, their adaptation may be difficult and controversial, and novel and innovative ways may have to be found. While this manual should be helpful within the limits of its mission, it should be viewed as open ended, and judges are encouraged to be innovative and creative to meet the needs of their cases, though remaining mindful of the bounds of existing law. ${ }^{79}$

Rather than describing the passive, neutral judicial function, the Man$u$ al begins with a highly expansive view of judicial control and supervision of complex cases. ${ }^{80}$ The Manual informs judges that multiple federal rules authorize substantial judicial case management and reminds judges that they also have extensive inherent powers to control the complex litigation in their courts. ${ }^{81}$ It states:

75. Manual for Complex Lrtigation, supra note 69.

76. In addition, federal judges trained through FJC programs generally are educated to the values of active judicial case management, a value reaffirmed in the 1990 Civil Justice Reform Act. See Civil Justice Reform Act of 1990, Pub. L. No. 101-650, 104 Stat. 5089, (codified at 28 U.S.C.A. $\$ \$ 471-482$ ) ("CJRA") (implementing civil justice expense and delay reduction plans to improve case management).

77. See Asbestos Claims Facility v. Berry \& Berry, 267 Cal. Rptr. 896, 903 n.2 (Ct. App. 1990) (noting that although Manual is without force of law, Federal Rules of Civil Procedure have codified some of its recommended procedures).

78. See David F. Herr, Annotated Manual for Complex Litigation, Third 3-4 (West Group 1999) (discussing that Manual has been used in both state and federal courts extensively for case management).

79. MANUAL FOR COMPlex Litigation, supra note 69 , $\$ 10.1$.

80. See id. $\S 20.1$ (stating that judge may exercise extensive supervision and control of litigation).

81. See Chambers v. NASCO, Inc., 501 U.S. 32, $43-46$ (1991) (discussing inherent powers of federal courts). 
Although not without limits, the court's express and inherent powers enable the judge to exercise extensive supervision and control of litigation. The Federal Rules of Civil Procedure, particularly Rules $16,26,37,42$, and 83 , contain numerous grants of authority that supplement the court's inherent power to manage litigation. Fed. R. Civ. P. 16(c)(12) specifically addresses complex litigation, authorizing the judge to adopt "special procedures for managing potentially difficult or protracted actions that may involve complex issues, multiple parties, difficult legal questions, or unusual proof problems." 82

Perhaps the Manual's most telling description of the activist judge is contained in the section that describes the attributes of effective case management. Here, the Manual states that "[e]ffective judicial management generally has the following characteristics":

- IT IS ACTIVE. The judge attempts to anticipate problems before they arise rather than waiting passively for matters to be presented by counsel. Because the attorneys may become immersed in the details of the case, innovation and creativity in formulating a litigation plan may frequently depend on the court.

- It is substantrve. The judge's involvement is not limited to procedural matters. Rather, the judge becomes familiar at an early stage with the substantive issues in order to make informed rulings on issue definition and narrowing, and on related matters, such as scheduling, bifurcation and consolidation, and discovery control. ${ }^{83}$

The Manual continues with additional attributes of effective judicial management, indicating that the judge's supervision should be timely, continuing, firm, fair and carefully prepared. ${ }^{84}$ These attributes, moreover, embody several of the core values incorporated into the 1990 Civil Justice Reform Act ("CJRA") ${ }^{85}$ that Congress enacted as a mandatory reform program on all ninety-four federal district courts. ${ }^{86}$

These general prescriptions, however, do not convey the level of detailed immersion of many federal judges in complex litigation. The management and resolution of complex cases is replete with examples of

82. Manual for Complex Litigation, supra note 69 , at $\S 20.1$ (footnote omitted).

83. See id. $\$ 20.13$.

84. See id. (noting further characteristics of effective judicial management).

85. Civil Justice Reform Act of 1990, Pub. L. No. 101-650, 104 Stat. 5089 (codified at 28 U.S.C.A. $\S \S 471-482$ ). See generally David Rauma \& Donna Stienstra, The Civil Justice Reform Act Expense and Delay Reductions Plans: A SOURCEBOOK 2 (F.J.C. 1995) (discussing purpose and statutory requirements of CJRA).

86. See 28 U.S.C.A. $\S 471$ (2000) (implementing program for civil justice expense and delay reduction plan). 
highly activist judges who have engaged in hands-on supervision of their complex cases. Through the use of court-appointed expert witnesses, ${ }^{87}$ special masters ${ }^{88}$ and science panels, ${ }^{89}$ federal judges have incrementally moved the judicial function towards that of an investigative and fact-finding institution. Many trial judges take an active role in trial-planning, data collection and damage sampling. ${ }^{90}$ Judges take an active role in creating administrative bureaucracies for claims filing and processing. ${ }^{91}$ Additionally, judges definitely take an active role in brokering and structuring aggregate settlements, ${ }^{92}$ approving those settlements and

87. See Manual for Complex Litigation, supra note 69 , at $\$ 21.21$ (discussing pretrial conferences and orders); see also Joe S. CEGIL \& Thomas E. Willging, Court-Appointed Experts: Defining the Role of Experts Appointed Under FedERAl Rule of Evidence 706 (Fed. Jud. Ctr. 1993) (discussing infrequent use of court-appointed experts); Reference Manual on Scientific Evidence. 1 (Fed. Jud. Ctr. 1994) (discussing purpose of MANUAL is to assist judges in managing expert evidence).

88. See FED. R. Crv. P. 53 (discussing appointment and role of special master in any pending action); MANUAL FOR COMPLEX LITIGATION, supra note $69, \S 21.52$ (noting use of special masters when issues are complicated). See generally Linda Silberman, Judicial Adjuncts Revisited: The Proliferation of Ad Hoc Procedure, 137 U. PA. L. Rev. 2131 (1989) (discussing use of judicial adjuncts in context of modern complicated litigation).

89. See Report of the Advisory Committee on Civil Rules and the Working Group on Mass Torts to the Chief Justice of the United States, in REPORT ON MAss TORT LiTIGATION, app. data (Feb. 15, 1999) [hereinafter REPORT ON MASS TORT LITIGATION] (noting use of science panels in breast implant litigation).

90. For a further discussion of the active role of trial judges in creating administrative procedures for claim filing, see infra notes 92-116 and accompanying text.

91. For a further discussion of the increasingly active role of trial judges, see infra notes 92-116 and accompanying text.

92. See Manual for Complex Litigation, supra note 69, at $\S 23.1$ (exploring trial judge's role in settlement of complex litigation). Significantly, the Manual suggests:

SeTtlement COUNSEl, SPECIAl MASTERs, OR EXPERTs. Despite their familiarity with the case, the attorneys conducting the litigation may not be those best suited to conduct settlement discussions. They are generally selected for their ability as litigators, while others may possess superior negotiation skills. They may also be hampered by personal antagonisms developed in the course of the litigation. The judge may therefore suggest that one or more of the parties engage special counsel for the purpose of conducting settlement negotiations, or designate settlement counsel separate from lead and liaison counsel .... Judges also have used special masters to assist in settlement of complex litigation and in post-settlement claims-resolution proceedings.

Id. $\S 23.13$.

The heavy-handed involvement of some managerial judges in the resolution of complex litigation has been criticized by academic commentators. See, e.g., Peter H. Schuck, The Role of Judges in Settling Complex Cases: The Agent Orange Example, 53 U. CHI. L. Rev. 337, 337 (1986) (discussing judge's involvement in settlement process); Leroy J. Tornquist, The Active Judge in Pretrial Settlement: Inherent Authority Gone Awry, 25 WillametTe L. Rev. 743, 745-46 (1989) (examining judicial role in pretrial settlement conferences). 
attorneys' fees ${ }^{93}$ and supervising implementation of . settlement agreements. ${ }^{94}$

The convergence of the judicial function with investigative fact-finding in complex litigation has been most evident in the expansive use of court-appointed expert witnesses and special masters. Judges have employed these "judicial surrogates" to engage in fact-finding, frame legal conclusions or administer remedies. ${ }^{95}$ Most prominently, judges have used special masters to collect and synthesize data about class claimants for the purpose of assessing damages awards. ${ }^{96}$

For example, Judge Jack Weinstein in the United States District Court for the Eastern District of New York employed a special master in asbestos class litigation to determine the factual question whether the defendant's financial assets constituted a limited fund for the purposes of class certification. ${ }^{97}$ The special master held evidentiary hearings and concluded with a finding of a limited fund. ${ }^{98}$ In the context of class action litigation, the proof of a limited fund normally is committed to the parties. ${ }^{99}$ In this instance, however, Judge Weinstein authorized independent fact-finding apart from any evidentiary presentation by the parties. ${ }^{100}$

In other examples of judicial fact-finding, Judge Robert Parker in the United States District Court for the Eastern District of Texas employed a special master to survey the gravity, extent and typicality of asbestos class members' claims - essentially an extensive fact-finding task. ${ }^{101}$ Similarly, Judge Carl Rubin employed the same special master in Ohio asbestos litigation to survey class claims and to create a sophisticated computer database for claims evaluation and processing. ${ }^{102}$

93. See Manual for Complex Litigation, supra note 69 , at $\$ 23.23$ (discussing and defining different types of side agreements to apportion damages).

94. See id. $\S 30.47$ (discussing administration of class settlement suits).

95. For a further discussion of the multiple uses of judicial surrogates, see infra notes 96-113 and accompanying text.

96. For a further discussion of the use of judicial surrogates in assessing damages awards, see infra notes $97-100$ and accompanying text.

97. See In re Joint E. \& S. Dists. Asbestos Litig., No. CV93-2129, 1993 WL 604077, at *1 (E.D. \& S.D.N.Y. July 1, 1993) (noting court appointment of special master for holding hearings and reporting on financial matters).

98. See id. (stating special master claimed that Keene is limited fund).

99. See, e.g., Doe v. Karadzic, 192 F.R.D. 133, 138-39 (S.D.N.Y. 2000) (noting that guidelines for class certification on limited fund rationale required plaintiffs to satisfy evidentiary burden).

100. See In re Joint E. \& S. Dists. Asbestos Litig., 1993 WL 604077, at *1 (recognizing need to efficiently determine. "whether separate adjudications would substantially impede the ability of the proposed class members to protect their interests").

101. See Jenkins v. Raymark Indus., Inc., 109 F.R.D. 269, 289 (E.D. Tex. 1985) (appointing special master to assist in factual determinations of disparities).

102. See Wayne D. Brazil, Special Masters in Complex Cases: Extending the Judiciary or Reshaping Adjudication?, 53 U. CHI. L. REV. 394, 399 (1986) (commenting on Special Master Francis McGovern in In re Related Asbestos Cases (N.D. Ohio 1980)). 
In addition to these examples, the federal judge supervising the litigation against the Estate of Ferdinand Marcos employed a special master to collect data on individual claims for the purposes of creating a damage extrapolation model. ${ }^{103}$ This special master spent months in the Philippines collecting fact information and reporting to the court. ${ }^{104}$ In the Georgine v. Amchem Products, Inc. ${ }^{105}$ class settlement, United States Federal District Judge Lowell Reed employed a special master to conduct an independent evaluation of past asbestos awards for the purpose of assessing whether a proposed classwide settlement was fair, adequate and reasonable. ${ }^{106}$

Moreover, federal judges in complex cases are moving in the direction of a more active role in fact-finding through the use of special science panels. The most prominent recent examples are the use of science panels by Federal Judges Sam Pointer and Jack Weinstein in the breast implant litigation. ${ }^{107}$

Judges have also employed special masters to propose trial plans, or judges have themselves created trial plans for complex cases. Thus, in Texas, Judge Robert Parker authorized a special master to propose a multi-stage trial plan for classwide resolution of asbestos claims, including resolution of classwide aggregate damages. ${ }^{108}$ Over the objections of both the plaintiff and defense counsel, Judge Parker issued a trial plan substantially based on the special masters' proposed plan, including the masters' legal justifications in support of the plan. ${ }^{109}$ Similarly, the presiding judge in the Ohio Bendectin litigation formulated a trifurcated trial plan that

103. See In re Estate of Ferdinand E. Marcos Human Rights Litig., MDL No. 840, Report of Special Master Sol Schreiber (Dec. 30, 1994) (noticing depositions of 137 randomly selected claimants and their witnesses).

104. See Hilao v. Estate of Marcos, 103 F.3d 767, 772 (9th Cir. 1996) (noting that court appointed special master to supervise compensatory damages).

105. 157 F.R.D. 246 (E.D. Pa. 1994), vacated, 83 F.3d 610 (3d Cir. 1996), affd, 521 U.S. 591 (1997).

106. See id. at 258-59 (appointing special master to determine whether proposed settlement was fair to class).

107. See Order No. 31, May 31, 1996, In re Silicone Gel Breast Implants Prods. Liab. Litig. (No. CV92-P-10000-S, MDL 926) (N.D. Ala. 1996) (appointing experts under Federal Rule of Evidence 706); Order No. 31B, June 13, 1996, In re Silicone Gel Breast Implants Prods. Liab. Litig. (No. CV92-P-10000-S, MDL 926) (N.D. Ala. 1996) (confirming order no. 31 to appoint experts); Orders 31C \& D, Aug. 23, 1996, In re Silicone Gel Breast Implants Prods. Liab. Litig. (No. CV92-P-10000-S, MDL 926) (N.D. Ala. 1996) (appointing experts); Order 31E, Oct. 31, 1996, In re Silicone Gel Breast Implants Prods. Liab. Litig. (No. CV92-P-10000-S, MDL 926) (N.D. Ala. 1996) (giving directions to science panel). See generally Erichson, supra note 66 (discussing science panels in breast implant litigation).

108. See generally Jack Ratliff, Special Master's Report in Cimino v. Raymark Industries, Inc., 10 Rev. Lrrig. 521 (1991) (discussing experience as special master in asbestos mass tort action).

109. See Order, Dec. 29, 1989, Cimino v. Raymark Indus., Inc. (No. B-86-0456(A) (1989) (E.D. Tex. 1989) (consolidating 3031 cases under FED. R. Crv. P. 42(a)), rev'd, In re Fibreboard Corp., 893 F.2d 706 (5th Cir. 1990); see also Linda S. Mullenix, Beyond Consolidation: Post-Aggregative Procedure in Asbestos Mass Tort Litigation, 
departed from the trial plans proposed by the plaintiff and defense counsel. ${ }^{110}$

In addition to the use of court-appointed experts, science panels and special masters, judges in complex litigation have used judge magistrates to take an activist, hands-on approach to resolving complex litigation. ${ }^{111}$ For example, in the United States District Court for the Eastern District of Texas, Judge Parker created and approved an alternative dispute resolution ("ADR") plan for resolving asbestos claims, ${ }^{112}$ which was essentially administered by a magistrate judge delegated with the task of implementing the ADR plan. ${ }^{113}$

Finally, another attribute of the judicial function that has been modified in complex litigation concerns the extent to which judges flexibly administer evidentiary rules. For example, most federal judges do not apply strict evidentiary rules to class certification hearings, and generally allow any and all evidence in support of, or in opposition to, a proposed class certification. ${ }^{114}$ Similarly, judges recognize rather loose evidentiary rules at class settlement hearings, again permitting virtually all testimony into the record. ${ }^{115}$ Moreover, it is not uncommon for judges involved in class certifications or settlement hearings to actively question witnesses providing testimony or to elicit testimony from objectors. ${ }^{116}$

This increased use of and reliance on judicial surrogates in complex litigation has reconfigured the role and function of the federal judge, and the looser judicial attitude towards evidentiary rules in some settings is striking. In modern complex litigation, then, the central role of adversariness has been diminished to the extent that judges no longer rely solely on the parties to frame legal issues, present facts or evaluate legal conclusions. Moreover, activist judges in complex litigation are perfectly willing to override the attorney's role in controlling and conducting the litigation,

32 WM. \& MARY L. Rev. 475, 493-94 (1991) (describing special master's trial plan and implementation in Cimino).

110. See In re Bendectin Litig., 857 F.2d 290, 295-96 (6th Cir. 1988) (noting that court trifurcated case instead of bifurcating case).

111. See Manual for Complex Lrtigation, supra note $69, \S 21.53$ (discussing 28 U.S.C. $\S 636(\mathrm{~b})(1)$, FED. R. CIv. P. 53(f), 72 and local rules and use of magistrate judge's assistance).

112. See Alternative Dispute Resolution Agreement, Jenkins v. Raymark (E.D. Tex. 1986) ("Jenkins II ADR") (recognizing Jenkins II ADR agreement as efficient and beneficial to defendant facing mounting pool of plaintiffs). See generally Mullenix, supra note 109, at 490-91 (describing genesis of Jenkins II ADR agreement).

113. See Mullenix, supra note 109, at 491-92 (noting Jenkins II ADR agreement implemented by Mag. Judge Hines).

114. See, e.g., id. at 550-51 (noting J. Parker's abandonment of idea to use court-appointed expert, instead allowing parties' experts to validate scientific methodology).

115. See id. at 551 (noting wide variation in judicial intervention during settlement).

116. See generally id. (emphasizing variable modes of judicial intervention and assistance in class certifications and settlement hearings). 
such as when the judge takes the lead in formulating the trial plan, examining witnesses or freely admitting various forms of testimony into court records.

Thus, the traditional model in which the party-adversaries frame the issues, present the facts and control the conduct of the case has been substantially modified by the judge's ability and willingness to engage independently in these activities. In many respects (that are not completely captured by the preceding description), the American federal judge presiding over complex litigation now often acts like his or her civil law counterpart.

\section{B. Convergence: The Right To a Jury Trial}

Although the Seventh Amendment guarantees the right to trial by jury, a right that litigating attorneys hold sacrosanct, almost all complex cases typically are resolved without recourse to a jury trial. Virtually no mass tort case, for example, has been tried to a jury. ${ }^{117}$ Indeed, the Seventh Amendment right to trial by jury is a waivable right, if the lawyers neglect to invoke it. ${ }^{118}$

Complex cases are settled, of course, in the "shadow" of the threat of a jury trial. But most practicing class action attorneys recognize that, in reality, the case in which they are involved will not be tried to a jury. Moreover, there is substantial academic literature that has urged the basic reform that lay juries should be eliminated in complex litigation, ${ }^{119}$ and that blue-ribbon juries or science panels be used instead to evaluate the complex legal and evidentiary issues in these cases. ${ }^{120}$

117. See Report of the Advisory Committee on Civil Rules and the Working Group on Mass Torts to the Chief Justice of the United States and to the Judicial Conference of the United States, in REPORT ON MAss TORT Litigation, supra note 89, app. D at 9 (discussing class action terminations).

118. See James, supra note $12, \S 8.1$ (discussing right to trial by jury).

119. See, e.g., Jay Tidmarsh \& Roger TrangsRud, Complex Litigation and THE ADVERSARY SYSTEM 1209-19 (1998) (suggesting that juries should be eliminated in complex and technical situations). Indeed, most recently in Professor Jack Friedenthal's review of the new Tidmarsh and Trangsrud complex litigation casebook, Professor Friedenthal noted the trend in thinking towards eliminating juries in complex litigation. See Jack Friedenthal, Tackling Complex Litigation, 74 Notre Dame L. Rev. 1301, 1309 (1999) (reviewing Jay Tidmarsh \& Roger TrangSRUd, Complex LitTigation AND THE AdVERSARY SYSTEM (1998)).

120. See, e.g., Dan Drazan, The Case for Special Juries in Complex Litigation, 72 JudicAture 292, 322 (1989) (suggesting juries of scientific experts for toxic tort cases); William V. Luneberg \& Mark A. Nordenberg, Specially Qualified Juries and Expert Non-Jury Tribunals: Alternative for Coping with the Complexities of Modern Civil Litigation, 67 VA. L. REV. 887, 899-900 (1987) (reviewing instances when expert juries are appropriate); Joseph C. Wilkinson, Jr. et al., A Bicentennial Transition: Modern Altermatives to Seventh Amendment Jury Trial in Complex Cases, 37 U. KAN. L. Rev. 61, 68-74 (1988) (citing theoretical alternatives to traditional juries); Charles W. Fournier, Note, The Case for Special Juries in Complex Litigation, 89 YALE L.J. 1155, 1157 (1980) (giving reasons why special juries work better in complex litigation); see also Douglas King, Comment, Complex Civil Litigation and the Seventh Amendment 
Notwithstanding that certain types of class actions are never actually tried to a jury, the contemporary class certification process now requires class proponents to engage in the interesting exercise of hypothesizing a mythological jury trial that everyone understands will never occur. At class certification, the plaintiff carries the burden of demonstrating that the proposed class action satisfies all the requirements for class certification. ${ }^{121}$ In Rule 23(b) (3) actions, the plaintiff additionally must show that the proposed class action is a superior means for resolving the dispute, which in turn requires a showing that the proposed class action will be "manageable."122

In order to show manageability, many courts now require that the class proponents present a trial plan demonstrating how the class action will be tried. ${ }^{123}$ The proposed trial plan typically will include suggestions for multi-phase trial stages, ${ }^{124}$ choice-of-law considerations ${ }^{125}$ and proposed jury instructions. ${ }^{126}$ The failure of the plaintiffs to explain to the court, in some detail, how the proposed action actually will be tried may serve to defeat the manageability factor. ${ }^{127}$ The presentation of such complex trial plans, however, carries an air of fabrication and conjuring.

In turn, defendants or objectors in complex cases often invoke the Seventh Amendment to challenge novel and innovative trial plans. ${ }^{128} \mathrm{De}-$ spite the hypothetical nature of these trials, courts have been willing to repudiate class certification based on the theoretical design of a trial that

Right to a Jury Trial, 51 U. CHI. L. Rev. 581, 584-604 (1984) (citing uses of special juries in eighteenth century English courts).

121. See Charles A. Wright et al., 7A Federal Practice and Procedure $\$ 1759$ (1986) (citing numerous cases for this proposition).

122. See FED. R. Crv. P. 23(b) (3) (D) (requiring class action to be superior and manageable).

123. See, e.g., Cimino v. Raymark Indus., Inc., 151 F.3d 297, 302 (5th Cir. 1998) (using trial plan to determine manageability).

124. See, e.g., Jenkins v. Raymark Indus., Inc., 109 F.R.D. 269, 274-82 (E.D. Tex. 1985) (using trial plan to determine propriety of multi-phase trial), aff $d, 782$ F.2d 468 (5th Cir. 1986).

125. See In re Sch. Asbestos Litig., 789 F.2d 996, 1007 (3d Cir. 1986) (discussing how trial plan is used to determine propriety of choice-of-laws).

126. See, e.g., In re Rhone-Poulenc Rohrer, Inc., 51 F.3d 1293, 1302-05 (7th Cir. 1995) (using trial plan to determine proper jury instructions).

127. See, e.g., Castano v. Am. Tobacco Co., 84 F.3d 734, 744-46 (5th Cir. 1996) (discussing how failure to produce trial plan defeats manageability); Rhone-Poulenc, 51 F.3d at 1297 (holding insufficiency of plan defeats certification).

128. See Cimino, 151 F.3d at 311, 321 (showing how defendant used Seventh Amendment in challenge of trial plan); Allison v. Citgo Petroleum Corp., 151 F.3d 402, 422-25 (5th Cir. 1998) (examining effect of Seventh Amendment on plan propriety); Castano, 84 F.3d at 751 (discussing effect of Seventh Amendment on plan propriety); Rhone-Poulenc, 51 F.3d at 1302-03 (discussing how proposed trial plan possibly violates Seventh Amendment Re-examination Clause); In re Fibreboard Corp., 893 F.2d 706, 709 (5th Cir. 1990) (discussing defendant's assertion that trial plan violates Seventh Amendment Right to Jury). 
never will occur. ${ }^{129}$ In addition, the Supreme Court has invalidated settlements on the ground that the settlement class could never have been certified as a litigation class, meaning that no court could have approved the class for actual trial. ${ }^{130}$ The United States Supreme Court has reached this conclusion twice in the past three years by engaging in post-hoc analyses of hypothetical trials that never occurred, but theoretically might have. ${ }^{131}$

This exercise in future trial planning (or retrospective settlement hindsight) is largely an exercise in literary imagination because a high percentage of class litigation is never tried to a jury. This is also true for complex litigation resolved through the Multidistrict Litigation Statute. ${ }^{132}$ The lack of actual jury trials in complex litigation, then, renders the debate over the Seventh Amendment right to a jury trial a largely academic exercise in the United States.

\section{Convergence: Punitive Damages}

Civil law countries do not have punitive damages. ${ }^{133}$ For American tort lawyers, the thought of a legal system without punitive damages is anathema. But in fact, many complex cases are settled without punitive damages at all. Although punitive damages may still play an important role in traditional bipolar litigation-and the newspapers are filled with reports of enormous punitive damage awards ${ }^{134}$ - punitive damages do not, in fact, play a major role in the resolution of most large-scale complex litigation. Indeed, it is difficult to identify many large-scale complex cases in which the settlement has included a punitive damage component. ${ }^{135}$

129. See Rhone-Poulenc, 51 F.3d at 1302-04 (holding structure of proposed trial defeats certification); Fibreboard, 893 F.2d at 712 (holding phase of proposed trial defeats certification).

130. See generally Ortiz v. Fibreboard Corp., 527 U.S. 815, 848 (1999) (holding that settlement not proper without certification of entire possible class); Amchem Prods., Inc. v. Windsor, 521 U.S. 591, 609 (1997) (holding that even for settlement purposes class must be certified as if for trial).

131. See Ortiz, 527 U.S. at 848-49 (holding that settlement not proper unless class certified for trial); Amchem, 521 U.S. at 609 (same).

132. See Herr, supra note 78, at 293 (showing most complex litigation under Multidistrict Litigation Statute never goes to trial). See generally David F. HERr, Multidistrict Litigation: Practice Before the Judicial Panel on Multidis. TRICr LITIGATION (1985 \& Supp. 1996) (discussing rarity of jury trials).

133. For a discussion of the lack of punitive damages in civil law countries, see supra notes 30-31 and accompanying text.

134. See, e.g., Barry Meier, Punitive Damages Added in Smoking Case Verdict, N.Y. Times, Mar. 28, 2000, at A14 (describing $\$ 20$ million punitive damage award in single-plaintiff California state action against cigarette manufacturer).

135. See Report on Mass Tort Litigation, supra note 89, app. (describing characteristics of numerous mass tort actions with estimated numbers and amounts of damage awards including punitive damages and amounts of settlements).

Frequently defendants will settle the litigation prior to trial of any punitive damage claim. See, e.g., Joseph P. Fried, More Diet Drug Lawsuits Ahead Despite Pro- 
Moreover, for a variety of reasons, punitive damage classes are rarely, if ever, certified by American courts. ${ }^{136}$

The availability of punitive damages varies among states. Not every state permits punitive damages. ${ }^{137}$ In addition, among the states that do, many states restrict or cap punitive damage awards. ${ }^{138}$ In some states, such as Texas, substantive tort law requires that the fact-finder establish a relationship of punitive damages to compensatory damages. ${ }^{139}$ The variations in the availability of punitive damages, in turn, effects the ability of plaintiffs to pursue punitive damages on a classwide or aggregate basis, which is often difficult, if not impossible, to accomplish.

Because both plaintiff and defense attorneys are aware of the legal restrictions and difficulties in seeking aggregate punitive damage awards in complex cases, punitive damages have become a bargaining chip that plaintiffs and defendants are likely to flexibly barter in negotiations. ${ }^{140}$ Punitive damages are typically "exchanged" by plaintiffs in return for a release from an affirmative defense, such as a statute of limitations, that otherwise would bar a claim. Alternatively, plaintiffs frequently settle aggregate claims for an amount that includes a reduced premium for punitive damages, but for a sum that is less than what the claimants otherwise might have recovered in individual trials. ${ }^{141}$

posed Class Action Accord, N.Y. Times, Mar. 28, 2000, at B7 (describing $\$ 3.75$ billion nationwide fen-phen class action settlement with no punitive damages).

136. See, e.g., In re Fed. Skywalk Cases, 680 F.2d 1175, 1183 (8th Cir. 1982) (rejecting certification of punitive damage class), rev'g 93 F.R.D. 415 (W.D. Mo. 1982); In re N. Dist. of Cal., Dalkon Shield IUD Prods. Liab. Litig., 693 F.2d 847, 857 (9th Cir. 1982) (holding that punitive damage class certification not available because out-of-state plaintiffs not available), rev'g 521 F. Supp. 1188 (N.D. Cal. 1981). But cf. Jenkins v. Raymark Indus., Inc., 109 F.R.D. 269, 281 (E.D. Tex. 1985) (certifying class for punitive damages), aff d, 782 F.2d 468 (5th Cir. 1986). See generally Linda S. Mullenix, Federal Practice: Complex Litigation-Punitive Damage Class Actions, NAT'L L.J., Jan. 24, 2000, at A18 (giving overview of punitive damage class actions).

137. See generally James R. McKown, Punitive Damages: State Trends and Developments, 14 REv. LiTIG. 419, 436 (1995) (giving overview of various state punitive damage rulings).

138. See id. (discussing punitive damage caps).

139. See Cimino v. Raymark Indus., Inc., 151 F.3d 297, 311-21 (5th Cir. 1998) (holding that punitive damages not proper unless sufficiently related to compensatory damages).

140. See generally Tom Baker, Transforming Punishment into Compensation: In the Shadow of Punitive Damages, 1998 WIS. L. REv. 211 (1998) (describing effect of punitive damage schemes on settlement negotiation); James A. Breslo, Taking the Punitive Damage Windfall Away From the Plaintiff: An Analysis, 86 Nw. U. L. REv. 1130 (1992) (analyzing punitive damage effect on negotiation); Thomas Koenig, The Shadow Effect of Punitive Damages on Settlements, 1998 WIS. L. REv. 169, 177 (1998) ("Freedom from punitive damages is the first concession that the tobacco companies have sought in forging a global settlement to the hundreds of thousands of tobacco claims.").

141. See Koenig, supra note 140 , at 1130 (demonstrating reduced settlement amounts effected by punitive damage claims). 
Therefore, similar to the right to jury trial, punitive damages in American complex litigation have been rendered a hypothetical and speculative component in the actual resolution of these cases. Just as the attorneys have no expectation of actually trying the litigation, the attorneys also have little expectation that any aggregate settlement will include a punitive damage award. In essence, then, the element of punitive damages has effectively been leeched from American complex litigation.

\section{Convergence: Discovery}

The process of civil discovery presents another interesting example of incremental convergence. The received wisdom in comparative law is that American federal discovery provides for more liberal discovery than any other legal system in the world. ${ }^{142}$ However, the Hague Convention on the Taking of Evidence Abroad in Civil or Commercial Matters, ${ }^{143}$ to which thirty countries are signatories, ${ }^{144}$ embodies an example of international comity and accommodation regarding fact-finding and investigation in civil litigation. ${ }^{145}$ Furthermore, the proposed American Law Institute's Transnational Rules of Civil Procedure ${ }^{146}$ include provisions that would effectively level the discovery playing field among civil and common law

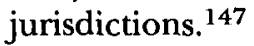

Moreover, in the discovery arena, the American trend has been this: since the Federal Rules of Civil Procedure created the regime of liberal discovery in 1938, every reform of the discovery rules has been to require more frank and early disclosure, and has been intended to circumscribe discovery abuse. ${ }^{148}$ These discovery reforms have been in response to the

142. For a further discussion of discovery under the American Federal Rules of Civil Procedure, see supra notes 20-23 and accompanying text.

143. Hague Convention on the Taking of Evidence Abroad in Civil or Commercial Matters, Mar. 18, 1970, 23 U.S.T. 2555, 847 U.N.T.S. 231 (codified at 28 U.S.C. $\$ 1781$ (1982 \& Supp. 1983)) [hereinafter Hague Convention].

144. See Treaties in Force: A list of Treaties and Other International Agreements of the United States in Force on January 1, 1999, at 399 (1999) (listing states that are parties to Hague Convention).

145. See generally Hague Convention, supra note 143 (expressly providing mechanisms through which United States courts could acquire evidence located in foreign countries).

146. Am. Law Inst., Transnational Rules of Civil Procedure, Discussion Draft (Apr. 1, 1999) (Professors Geoffrey C. Hazard, Jr. \& Michele Taruffo, Reporters).

147. See id. at 24-28 (proposed Rules 14-16) (setting forth transnational discovery rules); $c f$. Richard L. Marcus, Retooling American Discovery for the Twenty-First Century: Toward a New World Order?, 7 Tul. J. INT'L \& Comp. L. 153, 186 (1999) (doubting whether proposed rules contemplate discovery on American scale); Weintraub, supra note 22, at 415-22 (criticizing proposed transnational rules, particularly proposed discovery provisions).

148. See generally John S. Beckerman, Confronting Civil Discovery's Fatal Flaws, 84 MinN. L. Rev. 505 (2000) (recognizing abundance of proposed solutions to correct discovery problems); Richard L. Marcus, Discovery Containment Redux, 39 B.C. L. REv. 747 (1998) (stating that proposed amendments attempt to "contain the genie of broad discovery without killing it"); Linda S. Mullenix, The Pervasive Myth of 
realization that the federal discovery rules, rather than enhancing the factfinding process, often impede it at every possible juncture. ${ }^{149}$ In other words, for more than sixty years the Advisory Committee on Civil Rules has been amending the discovery rules to require more forthright disclosure and to eliminate game-playing as a litigation strategy.

The discovery reforms that the Advisory Committee has effectuated also reflect and embody the more conservative discovery practices of many civil law countries that allow at least some discovery prior to legal proceedings. ${ }^{150}$ American discovery rules have been amended to reduce or eliminate unnecessary or excessive discovery. Most prominent among these American discovery reforms have been amendments to restrict the time, place and manner of depositions, the number of depositions and the possibility of repetitive depositions. ${ }^{151}$ In addition, the discovery rules have been amended to limit the quantity and length of interrogatories. ${ }^{152}$

It is also sobering to reflect that the preponderance of American discovery disputes center on questions relating to various privileges and immunities that protect information from forced disclosure. ${ }^{153}$ In this

Pervasive Discovery Abuse: The Sequel, 39 B.C. L. REv. 683 (1998) (discussing significance of empirical research in amendment to federal discovery rules); Paul V. Niemeyer, Here We Go Again: Are the Federal Discovery Rules Really in Need of Amendment?, 39 B.C. L. REv. 517 (1998) (questioning whether rule changes can be made that will not incidentally undermine spirit of full disclosure); Stephen N. Subrin, Fishing Expedition Allowed: The Historical Background of the 1938 Federal Discovery Rules, 39 B.C. L. REv. 691 (1998) (noting that courts must balance discovery's broad theme with time, money and privacy concerns); Elizabeth G. Thornburg, Giving the "Haves" a Little More: Considering the 1998 Discovery Proposals, 52 SMU L. REv. 229 (1999) (noting that probable impact of amendments will be to curtail discovery); Carl Tobias, Discovery Reform Redux, 31 ConN. L. Rev. 1433 (1999) (finding Advisory Committee's 1998 proposed revisions relating to mandatory disclosure ironic because reports indicated that 1993 revisions had been effective).

149. See, e.g., Robert D. Cooter \& Daniel L. Rubinfield, Reforming the New Discovery Rules, 84 GEO. L.J. 61, 86 (1995) (stating that mandatory disclosure impedes settlement negotiations because release of large amount of information causes litigants' expectations to diverge); Griffin Terry, Comment, A Critical Analysis of the Formulation and Content of the 1993 Amendments to the Federal Rules of Civil Procedure, 63 U. CiN. L. REv. 869, 869 (1995) (noting that 1993 amendments were in response, in part, to "excessive cost and delay inherent in . . . litigation").

150. See Marcus, supra note 147, at 161-62 (noting that initial reforms to discovery included components of civil law).

151. See FED. R. Crv. P. 30(a), (d) (setting forth scope of permissible deposition); see also FED. R. Crv. P. 30 advisory committee's notes (1993 amendments) (stating that one "objective is to emphasize that counsel have a professional obligation to develop a mutual cost-effective plan for discovery in the case").

152. See FED. R. Crv. P. 33 (a) (stating "without leave of court or written stipulation, any party may serve upon any other party" twenty-five written interrogatories, including all discrete subparts); see also FED. R. Crv. P. 33 advisory committee's notes (1993 amendments) ("Experience . . . has confirmed that limitations on the number of interrogatories are useful and manageable.").

153. See, e.g., Charles A. Wright et al., Federal Practice \& Procedure CrvIL 2d $\$ 2016.1$ (1994) (detailing problems that courts face when litigants assert objections based on work product privilege). 
regard, American discovery doctrines are as restrictive, if not more so, than civil law jurisdictions. At any rate, the descriptions of the difference between American and civil law discovery, the availability of materials and access to information may be as overstated as in other comparisons of the American and civil law procedural process.

\section{E. Convergence: Financing Litigation and Attorney Fees}

With regard to financing litigation, two features characterize the comparative description of the civil law and American systems. In these standard renditions, civil law systems use the "loser pays" rule, and contingency fee arrangements are not permitted. ${ }^{154}$ In contrast, the American legal system requires that each side pay its own fees, and contingency fee contracts are permitted. ${ }^{155}$

Although these generalizations apply for simple or traditional litigation, the financing of complex litigation in each system actually is more nuanced and complicated than these generalizations indicate. For example, some civil law and other common law systems, such as Great Britain, have legal aid programs that subsidize plaintiffs' costs for pursuing aggregate relief. ${ }^{156}$ Thus, public and private funds may be combined to pool resources in order to pursue aggregate relief. Finland and Sweden have proposed class litigation statutes that would publicly finance aggregate litigation. ${ }^{157}$

In the United States, the so-called American rule is subject to numerous exceptions, such as fee-shifting statutes, the common fund doctrine and lodestar formulas for calculating attorney fees. ${ }^{158}$ In class action litigation, courts oversee fee petitions and approve, modify or reject fee petitions. ${ }^{159}$ Also, in class action litigation, defendants usually pay attorney

154. See W. Kent Davis, The Intermational View of Attorney Fees in Civil Suits: Why Is the United States the "Odd Man Out" in How It Pays Its Lawyers?, 16 ARIz. J. INT'L \& Comp. L. 361, 372-73, 409 (1999) (noting that most civil law nations do not permit contingency fees and adhere to loser pays rule).

155. See id. at 371-72, 398 (noting that United States permits contingency fees and generally requires litigants to pay their own costs of litigation regardless of outcome).

156. See Howlett, supra note 19, at 263-65 (1991) (concluding that civil law system better compensated plaintiffs with drug-induced fetal deformities).

157. See Draft Proposal for a Class Action Act, Committee Report of the Legislative Department of the Ministry of Justice $\$ 3.2 .4$ (Jan. 1995) (Fin.) (stating that party who requests that matter be resolved as class action may petition state for legal expenses); Official Report, Proposed Act on Class Actions $\$ \$ 54-67$ (1995) (Swed.) (detailing responsibility for legal expenses in class actions). See generally Per Henrik Lindblom, Individual Litigation and Mass Justice: A Swedish Perspective and Proposal on Group Actions in Civil Procedure, 45 Aм. J. ComP. L. 805 (1997) (arguing that Swedish class litigation statute would not affect substantive law, but would facilitate civil procedure).

158. See Manual for Complex Litigation, supra note $69, \S 24.12$ (discussing common fund, lodestar and statutory exceptions to American Rule).

159. See, e.g., Jonathan R. Macey \& Geoffrey P. Miller, The Plaintiffs' Attomey's Role in Class Action and Derivative Litigation: Economic Analysis and Recommendations 
fees, which is the "loser pays" rule without the concomitant obligation that the plaintiff pay the defendant's fees if the plaintiff loses. But Federal Rule of Civil Procedure 68, the "Offer of Judgment" rule, effectively holds a plaintiff liable for the defendant's post-offer costs if the plaintiff rejects an offer and then subsequently recovers less than the offer. ${ }^{160}$ The point is this: although commentators routinely recite the American rule as the leading characteristic of American attorney fees, each side rarely pays its own fees in complex litigation.

Finally, it is worthy to note that state attorneys general, allied with private attorneys, have created a new model for structuring and financing complex litigation in the United States. In this model, public auspices and funds join private attorneys with contractual fee agreements to pursue aggregate litigation against corporate defendants. State attorneys general pioneered this model in the late 1990 s against the tobacco companies ${ }^{161}$-a model that state attorneys general may employ in subsequent litigation against lead paint and gun manufacturers. ${ }^{162}$

These public-private financing transactions in complex litigation are far removed from those typically used to describe simple American fee arrangements. What is striking, however, is the degree of convergence with European common law and civil law systems that already have some degree of combined public and private financing of complex litigation.

\section{F. Legislative Solutions for Aggregate Disputes}

One of the most striking features of the ways in which European civil law and other common law countries resolve aggregate litigation is through legislation. Thus, some countries have resolved mass disaster

for Reform, 58 U. CHI. L. REv. 1, 48 (1991) (noting that judges review fee petitions in class action suits).

160. See Fed. R. Crv. P. 68 ("If the judgment finally obtained by the offeree is not more favorable than the offer, the offeree must pay the costs incurred after the making of the offer.").

161. See Wendy E. Wagner, Rough Justice and the Attomey General Litigation, 33 GA. L. Rev. 935, 957-61 (1999) (noting that Attorney Generals' involvement is integral part of holding tobacco industry accountable); of. Panel Discussion, The Tobacco Litigation and Attomeys' Fees, 67 Fordham L. Rev. 2827, 2827 (1999) (stating that suits were brought by private lawyers on behalf of states against tobacco industry, which entitled states percentage of recovery).

162. See, e.g., Robert A. Levy, Turming Lead into Gold: Plaintiffs' Lawyers, States and Localities Gear Up to Strip Billions from Paint Makers, Legal Times, Aug. 23, 1999, at 21 (referring to imminent lead paint litigation as "extortion" and arguing for loser pays rule); Corporate Brief, Business Watch, Paint Makers Sued Over Lead Poisoning, NAT'L L.J., Oct. 25, 1999, at B4 (noting Rhode Island has sued eight makers of lead paint for allegedly selling product that poisons children); The Week in Review, Target: Gun Manufacturers, NAT'L L.J., Apr. 12, 1999, at A6 (noting that Texas law allows state attorney general to sue gun manufacturers without prior legislative authorization); cf. Susan Borreson, Gun Litigation Unlikely to Mirror Success of Tobacco Suits, TEx. LAW., Jan. 18, 1999, at 4 ("[G] un loving culture . . . and a state law that protects gun manufacturers from liability . . . could impede such litigation ...."). 
claims by enacting legislation to provide compensation for injured claimants. India, for example, passed national legislation ${ }^{163}$ to resolve claims arising from the industrial accident in which lethal gas was released from a chemical plant operated by Union Carbide India Limited in Bhopal in December 1984. ${ }^{164}$ In addition, Japan passed legislation to compensate the child victims whose pregnant mothers had ingested thalidomide in the 1960 s. ${ }^{165}$ Often these legislative remedial schemes are financed by public funds as well as contributions from the private malfeasors. ${ }^{166}$

Many civil law countries also have enacted legislation in the aftermath of mass or aggregate disasters. ${ }^{167}$ The purpose of this post-disaster legislation is to provide standards of care, liability and remediation for future conduct. Germany, England and Japan have passed such legislation after their respective experiences with thalidomide litigation. ${ }^{168}$

In an emerging trend, some civil law and common law countries have enacted, or are in the process of enacting, statutory schemes to deal with aggregate claims. Finland and Sweden have each proposed extensive and detailed class action statutes. ${ }^{169}$ Various Canadian provinces ${ }^{170}$ and Australian states ${ }^{171}$ also have promulgated class action rules and statutes. In South America, Brazil has a consumer class action statutory scheme that includes a class action remediation provision. ${ }^{172}$ England also recently en-

163. See Jamie Cassels, The Uncertain Promise of Law: Lesson From Bhopal, $17 \mathrm{MD}$. J. INT'L L. \& TRADE 253, 255 (1993) (book review) (discussing various aspects of Bhopal Act); Tim Covell, The Bhopal Disaster Litigation: It's Not Over Yet, 16 N.C. J. INT'L L. \& Com. Reg. 279, 281-82 (1991) (same); Hanson Hosein, Unsettling: Bhopal and the Resolution of International Disputes Involving an Environmental Disaster, 16 B.C. Inr'l \& Comp. L. Rev. 285, 292 (1993) (same).

164. See In re Union Carbide Corp. Gas Plant Disaster, 809 F.2d 195, 197-98 (2d Cir. 1987) (affirming dismissal of claims brought in Southern District of New York on grounds of forum non conveniens, provided that defendant submits to jurisdiction of Indian courts).

165. See Howlett, supra note 19 , at $257-58$ (noting that legislation granted relief to all victims of fetal deformities, not just those that filed suit).

166. See id. at 257-58, 264, 267 (noting that victims are compensated by government as well as offending manufacturers).

167. See id. at 257 (noting that Sweden and Germany passed legislation following toxic tort disasters that reformed drug laws).

168. See id. at 252-58 (stating that Germany, England and Japan enacted legislation after thalidomide disaster).

169. For a further discussion of proposed class action legislation in Finland and Sweden, see supra note 157 and accompanying text.

170. See, e.g., An Act Respecting Class Proceedings, S.O., ch.6, (1992) (Can.) (stating guidelines for class action proceedings); An Act Respecting the Class Action, S.Q., ch.8, (1978) (Can.) (regarding class action suits).

171. See, e.g., Amendment Act 1991, 1992 Acts of the Parliament of the Commonwealth of Australia ("An Act to amend the Federal Court of Australia 1976.").

172. See Codico de Protecaodo Consumidor Brasileira [Brazilian Consumer Protection Code], Law No. 8078, Sept. 11, 1990, art. 91-100 (Braz.) (creating national consumer class actions). 
acted a statute providing for a group action. ${ }^{173}$ Significantly, in all these instances, these countries considered, but rejected, the American class action rule as the framework for resolving aggregate claims. ${ }^{174}$

The United States has been slow to embrace legislative solutions to aggregate mass torts or mass disasters. For more than sixty years, Congress has resisted attempts to resolve asbestos litigation through national legislation. ${ }^{175}$ Indeed, the rare congressional initiative has been for the opposite purpose, to immunize potential defendants from liability in advance of mass torts. For example, Congress enacted a statute to relieve swine flu manufacturers of liability for any claims arising from use of the vaccine. ${ }^{176}$

Although the United States Congress has eschewed legislative solutions to aggregate mass tort litigation, this historical resistance may erode in the coming years. Congress currently is considering comprehensive legislation to resolve the American asbestos litigation crisis ${ }^{177}$ in the aftermath of the Supreme Court's rejection in 1997 and 1999 of two global class action settlements of such claims. ${ }^{178}$ Thus, Congress may finally act to provide a legislative solution to this mass tort crisis, in light of the judicial branch's failure to resolve these claims.

Mass tort litigation, in particular, has demonstrated the apparent limits of the American legal system to resolve aggregate litigation. For many years, courts and commentators have suggested that Congress should legislatively resolve mass tort and other problematic aggregate litigation. ${ }^{179}$

173. See Christopher J. Maley, Survey, Toxic Torts: Class Actions in the United States and England, 19 SufFolK TransNAT'L L. Rev. 523, 528-29 (1996) (noting that England's group litigation rules were refined in 1962).

174. See, e.g., Lindblom, supra note 157 , at $822-23$ (noting that Swedish proposal for class actions considered criticisms of American class actions).

175. See Special Project, An Analysis of the Legal, Social, and Political Issues Raised by Asbestos Litigation, 36 VAND. L. Rev. 573, 780-81 (1983) (noting that ninety-seventh Congress failed to enact all three asbestos-related bills that were considered).

176. See National Swine Flu Immunization Program of 1976, Pub. L. No. 94 380, 90 Stat. 113 (1976) (establishing emergency national swine flu immunization program); see also In re Swine Flu Immunization Prods. Liab. Litig., 89 F.R.D. 695, 699 (D.D.C. 1981) ("Under the Act, the United States accepted primary responsibility for injuries caused by the manufacture, distribution or administration of this swine flu vaccine.").

177. See, e.g., Fairness in Asbestos Compensation Act of 1998, S. 2546, 105th Cong. (1998) (establishing legal standards to address suits arising out of asbestos exposure).

178. See Ortiz v. Fibreboard Corp., 527 U.S. 815, 864-65 (1999) (holding that it was inappropriate to combine individual tort claims); Amchem Prods., Inc. v. Windsor, 521 U.S. 591, 628-29 (1997) (holding that plaintiffs failed to meet Rule 23 class action requirements).

179. See, e.g., Ortiz, 527 U.S. at 857-58 (commenting that large compensation schemes for asbestos victims are for legislative consideration); see also id. at 865 (Rehnquist, C.J., concurring) (stating that proliferation of asbestos claims "cries out for a legislative solution"); Amchem, 521 U.S. at 598-99 ("Real reform . . . requires federal legislation creating a national asbestos dispute-resolution scheme."); United States Judicial Conference, Report of THE AD Hoc CoMmitTeE on AsbesTos Litigation 3 (1991) (stating belief that there should be "legislation . . .creat- 
The manifest failure of the American procedural system to adequately deal with such litigation may, in the twenty-first century, induce Congress to act with regard to certain types of aggregate litigation, where it has declined to do so in the past. There are numerous proposed bills and statutes that address both the substantive and procedural dimensions of aggregate litigation pending before Congress. ${ }^{180}$ Many of these bills have languished and faltered for years. ${ }^{181}$ Now, however, the wisdom of such legislative solutions may command renewed attention in Congress.

Although Congress has not generally enacted substantive legislation to deal with aggregate mass torts, it is noteworthy that Congress has, in the past, enacted statutory schemes to cope with some specialized mass claims. The two best examples are the Black Lung statutory scheme ${ }^{182}$ and federal environmental laws. ${ }^{183}$ The Black Lung statutes provide a historical model for compensating claimants for personal injury claims, ${ }^{184}$ and the federal Superfund provisions provide a historical legislative model for compensating for toxic tort contamination. ${ }^{185}$ Most European countries have extensive statutory schemes regulating environmental matters. ${ }^{186}$

ing a national asbestos dispute resolution scheme that permits consolidation of all asbestos claims in a single forum. ..."). See generally REPORT ON MAss TORT LitigaTION, supra note 89 , app. F (compiling various legislative proposals).

180. See, e.g., Class Action Fairness Act of 1998, S. 2083, 105th Cong. (1998) ("To provide for federal class action reform . . .."); Class Action Jurisdiction Act of 1998, H.R. 3789, 105th Cong. (1998) (enlarging federal jurisdiction over class actions); Multiparty, Multiforum Jurisdiction Act of 1997, H.R. 1857, 105th Cong. (1997) (providing federal jurisdiction for certain multiparty civil actions).

181. The premier example is the Multiparty, Multiforum Jurisdiction Act, which was first introduced in Congress in 1988 as part of the 1988 Judicial Improvements Act, and has subsequently been reintroduced in almost every legislative session since 1988. See Linda S. Mullenix, Mass Tort Litigation: Cases and MAterials at x (1996) (discussing Multiparty, Multiforum Jurisdiction Act).

182. Black Lung Benefits Act, 30 U.S.C. $\$ \$ 901-962$ (1988).

183. See, e.g., Comprehensive Environmental Response, Compensation, and Liability Act ("CERCLA"), 42 U.S.C. $\$ \$ 9601-9675$ (1994) (allowing governments or private parties to recover environmental cleanup costs from responsible party); see also Manual for Complex Litigation, supra note 69, $\$ 33.7$ (stating that CERCLA cases are related to mass tort claims because of large numbers of parties and complex litigation).

184. See Black Lung Benefits Act, 30 U.S.C. $\$ \S 901-962$ ("An Act to provide for the protection of the health and safety of persons working in the coal mining industry of the United States, and for other purposes.").

185. See CERCLA, 42 U.S.C. $\$ \$ 9601-9675$ (establishing right to recover cleanup costs of environmental disasters from responsible parties).

186. See generally Philippe Sands, European Community Environmental Law: The Evolution of a Regional Regime of International Environmental Protection, 100 YALE L.J. 2511 (1991) (stating that European Union member states experienced rapid environmental legislation growth between 1973 and 1987); Philippe Sands, European Community Environmental Lax: Legislation, the European Court of Justice and Common Interest Groups, 53 MoD. L. Rev. 685 (1990) (stating that European environmental legislation has increased drastically since 1973); Ann M. Linniger, Note, Liberalizing Standing for Environmental Plaintiffs in the European Union, 4 N.Y.U. ENVTL. L.J. 90 (1995) (stating that European Union member states maintain several statutorily imposed environmental regulations). 
Again, the theme of convergence with regard to legislative solutions for mass torts and other aggregate litigation is striking. The United States created the class action rule, but has steadfastly avoided substantive legislative solutions to aggregate litigation. Most civil law countries, in contrast, have steadfastly avoided the class action rule, but have provided for substantive legislative solutions to aggregate claims. At the beginning of the twenty-first century, however, civil law countries are now embracing class action-like statutory schemes, and the American Congress is giving new scrutiny to substantive legislative solutions to mass torts. By the end of the century, all countries may have some version of a class rule, with parallel substantive legislation for resolving specialized aggregate tort claims.

\section{Conclusion}

Civil lawyers and scholars in Europe, South America, Australia and Canada have studied the American way of resolving complex litigation. As a result, many of these countries have created methods for resolving complex litigation that resemble American aggregate procedures, while at the same time rejecting the problematic procedures and doctrines involved in American class action litigation.

Very few civil law countries have a class action rule, but civil law jurisdictions do resolve aggregate litigation. Many civil law systems have studied the American class action rule and yet none have adopted it wholesale. Some civil law countries have adopted class-action style rules or legislation, with interesting variations on American themes. These jurisdictions have learned from the American experience of resolving complex litigation and have adopted the most attractive features from the American experience. These countries also have taken note of the difficulties and complications entailed in the American legal system's frustrations and failures in resolving complex cases.

In contrast, very little of the civil law experience has permeated or influenced the American understanding of the ways in which other nations resolve complex litigation. In the twenty-first century, then, lessons from abroad may begin to better inform the American legal community about other methods for complex dispute resolution. As American lawyers begin to work on a global stage, increased education about civil law systems may encourage American lawyers and judges to rethink the ways in which the American legal system attempts to resolve aggregate litigation. Just as civil lawyers have learned a great deal from the American experience, American lawyers may begin to learn a great deal from the civil law experience with resolving aggregate claims. Such exposure, conversation, study and education may, in turn, induce new ways of doing things, both for the American and civil law systems. Complex litigation in the twentyfirst century, then, may result in an interesting convergence of substantive and procedural thinking. 
[Vol. 46: p. 1 